\title{
Comparison of ground water quality between CEPZ industrial area and Hathazari non industrial area in Chittagong, Bangladesh
}

\author{
N. Islam*1 ${ }^{1}$ A. J. M. Morshed ${ }^{2}$ and D. P. Paul ${ }^{1}$ \\ ${ }^{1}$ Department of Physics, University of Chittagong, Chittagong-4331, Bangladesh. \\ ${ }^{2}$ Bangladesh Council of Scientific and Industrial Research, Chittagong-4220, Bangladesh.
}

\begin{abstract}
Assessment of the quality of underground water is an important issue for the safety of mankind who uses this as drinking water and other purposes. For this reason, the present research activities have been focused on various essential physico-chemical parameters such as $\mathrm{pH}$, electrical conductivity, total solids, total suspended solids, total dissolved solids, total hardness, turbidity, sulphate, nitrite, nitrate, phosphate, chloride, total alkalinity, arsenic, iron, manganese, chromium, nickel, cadmium, lead, magnesium, potassium, calcium, cobalt, mercury, copper and zinc of water samples from study area. In Chittagong Export Processing Zone (CEPZ) industrial area, most of the values of physico-chemical parameters for collected samples have exceeded the acceptable range of World Health Organization (WHO) and Bangladesh Standard and Testing Institute (BSTI). On the other hand, in Hathazari non-industrial area, almost all the values of both physical and chemical parameters as well as the trace metals have not crossed the acceptable limit according to WHO and BSTI.
\end{abstract}

Keywords: Trace metals, physico-chemical, underground water, industrial area, comparison, non-industrial area, Bangladesh.

\section{Introduction}

The quality of water depends on its physical and chemical characteristics (Kumar and James, 2013). Underground water is much clean and free from pollution than surface water. But prolonged discharge of industrial effluents, domestic sewage, nuclear explosion waste and solid waste dumping causes the groundwater to become polluted and created health problems (Craun et al. 1999). When waterborne bacteria and virus enter the potable water various types of dangerous diseases such as diarrhoea, cholera, polio, typhoid, hepatitis etc. are appeared in our body (Sharma et al. 2014 and Achakzai et al. 2014). Estimated 80\% of all diseases (Shivasharanappa et al. 2012) and over one third of deaths in developing countries are caused by the consumption of contaminated water and on the average as much as one tenth of each person's productive time is sacrificed to water-related diseases (Ahmed et al. 2011). Waste products from industries are very dangerous to the environment (Rahman, 1992). The CEPZ area has been chosen as sampling zone. Because, more than hundreds of factories such as garments, textile, garment accessories, metal products, tiny towel, knitting \& other textile products, footwear \& leather goods, ropes, electronics \& electrical goods, tent, service oriented industries, sports goods, plastic goods, fishing reel \& golf equipment, power industry and caps etc. have situated here and lot of manpower involved in this factories/industries are living in this sides. These factories contribute to environmental pollution by heavy metals like mercury, cadmium, lead, zinc, chromium, arsenic etc. These metals are essential for human body in small doses. But a huge amount of heavy metals is deadly toxic to human (Mohod and Dhote 2013, Heileslassie and Gebremedhin, 2015). Many diseases such as kidney damages, loss of hair, damage of nail and teeth, stomach pains, renal damage, cancer, lung diseases, neural disorder, insomnia and finally mental depression may arise in the body due to consumption of heavy metal contaminated drinking water (Tadiboyina and Ptsrk, 2016 and Salem et al. 2000). Heavy metals are contacted with soil and surface water. The current research has been compared between ground water of industrial and non-industrial region. Hence, the samples have collected from both industrial and non-industrial area and analyzed using standard procedures.

\section{Materials And Methods}

Collection and preservation of samples: Samples from different points of study area were collected for present experiments. The roughly distance between two sampling points was about 0.5 kilometer. The sampling location, date of collection and depth as well as their corresponding geographical position are shown in Table I and in Figure $1 \& 2$. The geographical position was measured (from $\mathrm{C} 1$ to $\mathrm{C} 8$ and $\mathrm{H} 1$ to H8) by GPS machine (Model No.: Germany Gps76CSX). Samples were also collected from tube-wells after discarding water for the first three minutes. High density plastic bottles of one liter capacity were used for the collection of samples cleaned by rinsing thoroughly with $10 \%$ of concentrated nitric acid $\left(\mathrm{HNO}_{3}\right)$ followed by repeated washing with 
distilled water. The bottles were also washed with the sample water before filling up. The collected samples were marked with identification number to the bottle and then transferred to the BCSIR Laboratories Chittagong, Bangladesh.

Experimental section: Different water parameters were determined using the following methods:

Atomic Absorption Spectrophotometer (Thermo-scientific, iCE -3300, 3000 series, USA) has been used for the determination of metals such as arsenic, mercury, iron, lead, nickel, cobalt, cadmium, copper, zinc, manganese, chromium, calcium, potassium and magnesium. Total alkalinity, chloride as well as total hardness were quantified by titrimetric methods. UV- Visible spectrophotometer (Model - UV 1800, Shimadzu, Japan) has been used for the determination of phosphate, nitrite, nitrate and sulphate. Electrical conductivity (EC), $\mathrm{pH}$ and turbidity were determinated using EC meter (Model no. 3/0513261. Germany), pH meter (model no. pH5011) and turbidity meter (Lovibond, Turb Direct, SN 09/1275, Germany) respectively. Gravimetric method has been applied for the determination of total solids (TS), total dissolved solids (TDS), and total suspended solids (TSS).

\section{Results And Discussion}

Physico-chemical parameters of ground water samples from industrial (CEPZ) and non-industrial (Hathazari) area are shown in [Table II \& III] and the concentration of trace elements of these samples from both areas are mentioned in [Table IV \& V]. The current study has shown that, $\mathrm{pH}$ value was obtained in the range of (6.4-7.72) for CEPZ and (5.3-7.3) for Hathazari area. Both the ranges have not exceeded permissible limit (WHO 2011). Electrical conductivity of the samples from industrial and non-industrial areas was found in the range of (240-7300) $\mu \mathrm{S} / \mathrm{cm}$ and (50-720) $\mu \mathrm{S} / \mathrm{cm}$ respectively. According to WHO guidelines (WHO 2011) six samples $(\mathrm{C} 3, \mathrm{C} 4, \mathrm{C} 5, \mathrm{C} 6, \mathrm{C} 7 \& \mathrm{C} 8)$ in industrial area have crossed the acceptable level of EC. The values of total solids have noted in the range of (182-19798)ppm for CEPZ and (45-512)ppm for Hathazari area. It was observed that seven samples (C1, C3, C4, C5, C6, C7 \& C8) from CEPZ area have exceeded the recommended limit of total dissolved solids (WHO 2011). The range of total suspended solids was (14-15970)ppm and (2142)ppm for CEPZ and Hathazari area respectively. The highest value of TSS was obtained from C4 and the lowest one was also obtained from H7. In industrial area, the level of Total hardness (TH) and Total alkalinity have recorded in the range of (80-848)ppm and (38.4-755.2) ppm respectively. But in non-industrial area, the range of Total Hardness and Total Alkalinity have obtained $(20-310)$ ppm and $(38.4-307.2) p p m$ respectively. A total of seven samples (C3, C4, C5, C6, C7, C8 \& H8) from both areas have shown higher value of TH (BDS 1240:2001). On the other hand, total alkalinity of five samples (C4, C5, C6, C7 \& C8) from CEPZ and one (H8) from Hathazari have crossed the standard limit (Kumar et al. 2014). Turbidity was found in the range of (1.13367)NTU. Almost all the samples excluding $\mathrm{C} 2 \& \mathrm{H} 2$ have exceeded the admissible level of turbidity (WHO 1993). The range of (BDL-7)ppm, BDL, (BDL-20)ppm, and (BDL-60)ppm has found for nitrate, nitrite, phosphate, and sulphate respectively. Chloride was found in the range of (15-2900)ppm. Excess of chlorides have indentified in the seven samples named C1, C3, C4, C5, C6, C7, \& C8 from industrial area (WHO 1993). But in non-industrial area, the values of chlorides for all the samples were not higher than the standard limit (WHO 1993) [Table II \& III].In both areas, the concentration of trace metals has estimated in the range of (19.2 - 782.4)ppm for magnesium. Maximum concentration of magnesium was observed in C4 from CEPZ and minimum in $\mathrm{H} 2$ from Hathazari. Eight samples viz. C1, C3, C4, C5, C6, C7, C8 \& H8 have crossed the permissible level of magnesium (WHO 1993). The concentrations of potassium have noted in the range of (2.64 - 61.27)ppm while the concentrations of calcium have found within the recommended limit (BDS 1240:2001). But according to WHO guidelines seven samples of potassium except C2 from CEPZ and one sample (H8) from Hathazari have exceeded the acceptable level (WHO 1993). The concentrations of manganese and iron from both areas have reported in the range of (BDL - 1.17)ppm and (BDL - 23.39)ppm respectively. The highest value of manganese has found in $\mathrm{C} 1$ and the lowest in both $\mathrm{C} 2 \& \mathrm{H} 2$. Three samples named $\mathrm{C} 1, \mathrm{C} 4$ \& $\mathrm{C} 5$ from industrial area have gone over the permissible limit of manganese (WHO 1993) as well as twelve samples from both areas have also shown the highest value of Iron than the standard level (BDS 1240:2001). On the other hand, nine metals like cobalt, nickel, copper, zinc, lead, cadmium, arsenic, mercury and chromium from industrial and non-industrial areas have shown the concentration within the recommended limit according to WHO standard value (WHO 1993) [Table IV \& V]

\section{Conclusions}

The quality of water is an important issue for utilization in domestic as well as drinking purposes. Many severe diseases occur in human body due to consumption of contaminated water. The present research has disclosed that the quality of ground water from industrial area is poorer than the non-industrial area. Because, the probability of the environmental pollution in industrial area is very high cause of discharging various hazardous substances such as chemicals, fertilizers, pesticides, gas, dyes etc. These toxic substances are assorted with soil and then mixed slowly with ground water. Thus, it is more essential to take perfect initiative for 
treating of drinking water in this area. Moreover, the hazardous chemicals from different industries must be treated before discharging in the environment.

\section{Acknowledgement}

The authors are grateful to the authority of Bangladesh Council of Scientific and Industrial Research (BCSIR) for providing all the supports including machineries as well as their good co-operation during research works. The authors are also grateful to the professors of the Department of Physics, University of Chittagong for supervising in this study. Finally, the authors would like to express their grateful thanks to the inhabitants of both industrial and non-industrial region due to assist the collection of samples.

\section{References}

[1] Achakzai AKK, Bazai ZK, Afzal M and Hanif U (2014). Physicochemical status of drinking water of Quetta districts. American-Eurasian Journal of Toxicological Sciences, 6: 62-67

[2] Ahmed MJ, Haque MR and Rahman MM (2011). Physicochemical Assessment of surface and Groundwater Resources of Greater Noakhali District of Bangladesh. Internation Journal of Chemical science and Technology, 1: $1-10$

[3] Craun GF, Calderon RL (1999). "Water-borne disease outbreaks: their causes, problems, and challenges to treatment barrier, AWWA manual M-48: water-borne pathogens", American Water Works Association, Denver, USA.

[4] Haileslassie $\mathrm{T}$ and Gebremedhin K (2015). Hazards of heavy metal contamination in ground water. International Journal of Technology Enhancements and Emerging Engineering Research, 3: 1 - 6.

[5] Kumar PJS and James EJ (2013). Physicochemical parameters and their sources in groundwater in the Thirupathur region, Tamil Nadu, South India. Appl Water Sci., 3: 219 - 228.

[6] Kumar A, Zaiad GM, Awheda IM and Fartas FM (2014). Physico-chemical Analysis of Ground Water in Different Sites of Al-khums City, Libya. International Journal of Science and Research (IJSR). 3:2395-2398.

[7] Mohod CV and Dhote J (2013). Review of heavy metals in drinking water and their effect on human health. International Journal of Innovative Research in Science, Engineering and Technology, 2: 2992 - 2996.

[8] Rahman K (1992). Industrial Pollution and Control; for sustainable Development. In Training Manual on Environment Management in Bangladesh. DoE, Dhaka, 1992, pp184.

[9] Salem HM, Eweida EA and Farag A (2000). Heavy metals in drinking water and their environmental impact on human health. ICEHM 2000, Cairo University, Egypt, pp542 - 556.

[10] Sharma B, Pandey B and Paikara D (2014). Analysis of Physico-chemical characteristics of ground water. Indian J. Sci. Res. $9: 154-157$.

[11] Shivasharanappa, Srinivas P and Huggi MS (2012). Study on the physico-chemical characteristics of ground water of Bidar City and its industrial area. International Journal of Applied Biology and Pharmaceutical Technology, 3: 359 367.

[12] Tadiboyina R and Ptsrk PR (2016). Trace analysis of heavy metals in ground waters of Vijayawada Industrial Area. International Journal of Environmental \& Science Education, 11: 3215 - 3229.

[13] WHO (2011). Guidelines for drinking water quality world health organization, IV edn. WHO Geneva.

[14] WHO (1993). Guideline for drinking water quality, Vol 2- Health criteria and other supporting information and Vol 3- Drinking water quality control in small community supplies. WHO Geneva.

Table I: Summery of the sample (with geographical position) collected from the CEPZ and Hathazari.

\begin{tabular}{|c|c|c|c|c|}
\hline \multirow[t]{2}{*}{ Sample ID } & \multirow{2}{*}{$\begin{array}{c}\text { Date of } \\
\text { collection }\end{array}$} & \multicolumn{2}{|c|}{ Geographical position } & \multirow[t]{2}{*}{ Depth in Feet } \\
\hline & & Latitude & Longitude & \\
\hline $\mathrm{C} 1$ & $31-10-2015$ & $22^{\circ} 17.235^{\prime} \mathrm{N}$ & $91^{\circ} 46.825^{\prime} \mathrm{E}$ & 700 \\
\hline $\mathrm{C} 2$ & $31-10-2015$ & $22^{\circ} 16.754^{\prime} \mathrm{N}$ & $91^{\circ} 46.620^{\prime} \mathrm{E}$ & WASA \\
\hline $\mathrm{C} 3$ & $31-10-2015$ & $22^{\circ} 16.717^{\prime} \mathrm{N}$ & $91^{\circ} 46.17^{\prime} \mathrm{E}$ & 110 \\
\hline $\mathrm{C} 4$ & 31-10-2015 & $22^{\circ} 16.716^{\prime} \mathrm{N}$ & $91^{\circ} 46.592^{\prime} \mathrm{E}$ & 120 \\
\hline $\mathrm{C} 5$ & $31-10-2015$ & $22^{\circ} 16.681^{\prime} \mathrm{N}$ & $91^{\circ} 46.573^{\prime} \mathrm{E}$ & 100 \\
\hline C6 & $31-10-2015$ & $22^{\circ} 17.92^{\prime} \mathrm{N}$ & $91^{\circ} 46.855^{\prime} \mathrm{E}$ & 150 \\
\hline $\mathrm{C} 7$ & $31-10-2015$ & $22^{\circ} 17.737^{\prime} \mathrm{N}$ & $91^{\circ} 46.828^{\prime} \mathrm{E}$ & 130 \\
\hline $\mathrm{C} 8$ & 31-10-2015 & $22^{\circ} 17.798^{\prime} \mathrm{N}$ & $91^{\circ} 46.821^{\prime} \mathrm{E}$ & 110 \\
\hline H1 & $03-11-2015$ & $22^{\circ} 47^{\prime} 1121^{\prime \prime} \mathrm{N}$ & $91^{\circ} 79^{\prime} 3580^{\prime \prime} \mathrm{E}$ & 360 \\
\hline $\mathrm{H} 2$ & $03-11-2015$ & $22^{\circ} 47^{\prime} 6068^{\prime \prime} \mathrm{N}$ & $91^{\circ} 81^{\prime} 2883^{\prime \prime} \mathrm{E}$ & 320 \\
\hline H3 & $03-11-2015$ & $22^{\circ} 46^{\prime} 1923^{\prime \prime} \mathrm{N}$ & $91^{\circ} 81^{\prime} 6410^{\prime \prime} \mathrm{E}$ & 300 \\
\hline $\mathrm{H} 4$ & 03-11-2015 & $22^{\circ} 46^{\prime} 7377^{\prime \prime N}$ & $91^{\circ} 81^{\prime} 6411^{\prime \prime} \mathrm{E}$ & 350 \\
\hline $\mathrm{H} 5$ & 03-11-2015 & $22^{\circ} 45^{\prime} 7899^{\prime \prime} \mathrm{N}$ & $91^{\circ} 81^{\prime} 3580^{\prime \prime} \mathrm{E}$ & 220 \\
\hline $\mathrm{H} 6$ & 03-11-2015 & $22^{\circ} 44^{\prime} 7899^{\prime \prime} \mathrm{N}$ & $91^{\circ} 81^{\prime} 5963 " \mathrm{E}$ & 675 \\
\hline $\mathrm{H} 7$ & $03-11-2015$ & $22^{\circ} 44^{\prime} 5722^{\prime \prime} \mathrm{N}$ & $91^{\circ} 81^{\prime} 5119^{\prime \prime} \mathrm{E}$ & 220 \\
\hline $\mathrm{H} 8$ & $03-11-2015$ & $22^{\circ} 77^{\prime} 2097 " \mathrm{~N}$ & $91^{\circ} 57^{\prime} 5192^{\prime \prime} \mathrm{E}$ & 40 \\
\hline
\end{tabular}

$[C=$ Chittagong Export Processing Zone (CEPZ) Area, H = Hathazari Area $]$ 


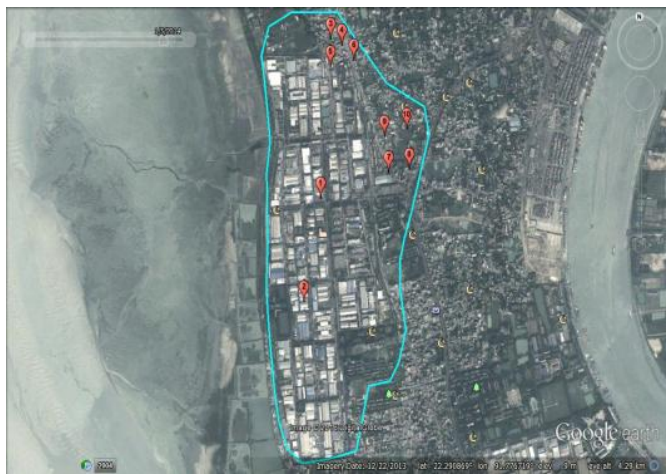

Figure 1 Map showing sample collection points of CEPZ area (Industrial area).

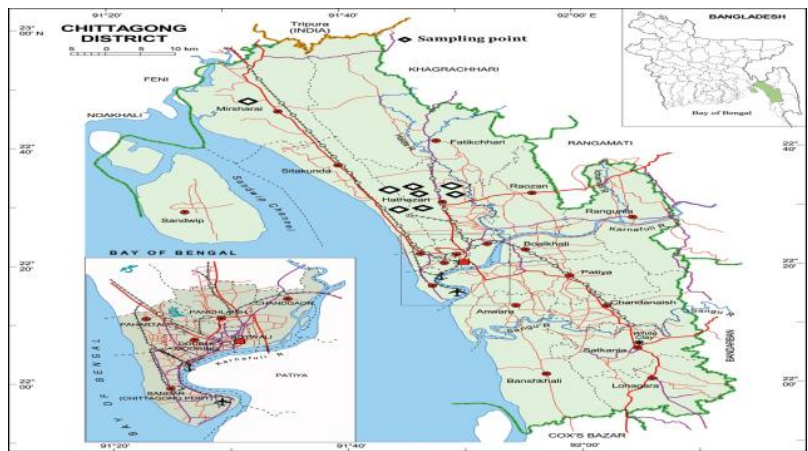

Figure 2 Map showing sample collection points of Hathazari (Non-industrial area).

Table II: Physico-chemical parameters of ground water in industrial area (CEPZ).

\begin{tabular}{|c|c|c|c|c|c|c|c|c|c|}
\hline Parameters & Units & C1 & C2 & C3 & C4 & C5 & C6 & C7 & C8 \\
\hline EC & $\mu \mathrm{S} / \mathrm{cm}$ & 1230 & 240 & 7300 & 5250 & 3400 & 4650 & 2940 & 2620 \\
\hline $\mathrm{pH}$ & & 7.72 & 7.1 & 6.9 & 6.4 & 6.8 & 6.9 & 7.1 & 7 \\
\hline Turbidity & $\mathrm{NTU}$ & 35 & 1.13 & 36.5 & 367 & 115 & 70 & 9.78 & 42 \\
\hline TDS & $\mathrm{ppm}$ & 930 & 156 & 4821 & 3828 & 2358 & 3099.8 & 1706 & 1470 \\
\hline TSS & $\mathrm{ppm}$ & 40 & 26 & 81 & 15970 & 126 & 160.2 & 56 & 14 \\
\hline TS & $\mathrm{ppm}$ & 970 & 182 & 4902 & 19798 & 2484 & 3260 & 1762 & 1484 \\
\hline Total Hardness & $\mathrm{ppm}$ & 125 & 80 & 400 & 848 & 425 & 536 & 300 & 420 \\
\hline Total Alkalinity & $\mathrm{ppm}$ & 51.2 & 38.4 & 89.6 & 524.8 & 755.2 & 473.6 & 550.4 & 512 \\
\hline Nitrate & $\mathrm{ppm}$ & $\mathrm{BDL}$ & $\mathrm{BDL}$ & 7 & 4 & 5 & 6 & 2 & $\mathrm{BDL}$ \\
\hline Nitrite & $\mathrm{ppm}$ & $\mathrm{BDL}$ & $\mathrm{BDL}$ & $\mathrm{BDL}$ & $\mathrm{BDL}$ & $\mathrm{BDL}$ & $\mathrm{BDL}$ & $\mathrm{BDL}$ & $\mathrm{BDL}$ \\
\hline Phosphate & $\mathrm{ppm}$ & $\mathrm{BDL}$ & $\mathrm{BDL}$ & 20 & $\mathrm{BDL}$ & 3 & 12 & 17 & 18 \\
\hline Sulphate & $\mathrm{ppm}$ & $\mathrm{BDL}$ & 5 & 25 & 10 & 50 & $\mathrm{ND}$ & 30 & 60 \\
\hline Chloride & $\mathrm{ppm}$ & 500 & 40 & 2900 & 1650 & 1200 & 1550 & 900 & 650 \\
\hline
\end{tabular}

Table III: Physico-chemical parameters of ground water in non-industrial area (Hathazari).

\begin{tabular}{|c|c|c|c|c|c|c|c|c|c|}
\hline Parameters & Units & H1 & H2 & H3 & H4 & H5 & H6 & H7 & H8 \\
\hline EC & $\mu \mathrm{S} / \mathrm{cm}$ & 50 & 90 & 240 & 130 & 330 & 130 & 120 & 720 \\
\hline $\mathrm{pH}$ & & 5.3 & 6.2 & 6.1 & 5.7 & 6.1 & 5.7 & 6.3 & 7.3 \\
\hline Turbidity & $\mathrm{NTU}$ & 12.3 & 3.85 & 12.5 & 28.1 & 65.1 & 83.1 & 21.7 & 41.8 \\
\hline TDS & $\mathrm{ppm}$ & 32.5 & 58.5 & 156.5 & 90 & 215 & 85 & 78 & 468 \\
\hline TSS & $\mathrm{ppm}$ & 12.5 & 6 & 136 & 142 & 33 & 28 & 2 & 44 \\
\hline TS & $\mathrm{ppm}$ & 45 & 64.5 & 292.5 & 232 & 248 & 113 & 80 & 512 \\
\hline Total Hardness & $\mathrm{ppm}$ & 20 & 24.5 & 80 & 52 & 86 & 44 & 50 & 310 \\
\hline Total Alkalinity & $\mathrm{ppm}$ & 38.4 & 76.8 & 64 & 76.8 & 102.4 & 76.8 & 89.6 & 307.2 \\
\hline Nitrate & $\mathrm{ppm}$ & BDL & BDL & BDL & BDL & BDL & BDL & BDL & 0.8 \\
\hline Nitrite & $\mathrm{ppm}$ & BDL & BDL & BDL & BDL & BDL & BDL & BDL & BDL \\
\hline Phosphate & $\mathrm{ppm}$ & BDL & BDL & BDL & BDL & BDL & BDL & BDL & 1 \\
\hline Sulphate & $\mathrm{ppm}$ & BDL & BDL & BDL & BDL & BDL & BDL & BDL & BDL \\
\hline Chloride & $\mathrm{ppm}$ & 15 & 20 & 48 & 18 & 80 & 24 & 15 & 100 \\
\hline
\end{tabular}


Comparison of ground water quality between CEPZ industrial area and Hathazari non ....

Table IV: Concentration of trace metals of ground water from industrial area (CEPZ)

\begin{tabular}{|c|c|c|c|c|c|c|c|c|c|}
\hline Metals & Units & C1 & C2 & C3 & C4 & C5 & C6 & C7 & C8 \\
\hline Magnesium & $\mathrm{ppm}$ & 160.8 & 28.8 & 322.2 & 782.4 & 560.8 & 478.4 & 308 & 428 \\
\hline Potassium & $\mathrm{ppm}$ & 13.23 & 3.08 & 55.10 & 61.27 & 58.49 & 49.71 & 42.73 & 37.38 \\
\hline Calcium & $\mathrm{ppm}$ & 27.2 & 11.2 & 28.8 & 65.6 & 19.2 & 57.6 & 32 & 24 \\
\hline Manganese & $\mathrm{ppm}$ & 1.17 & $<0.01$ & 0.08 & 0.93 & 0.81 & 0.33 & 0.04 & 0.05 \\
\hline Iron & $\mathrm{ppm}$ & 23.39 & $<0.01$ & 2.07 & 15.22 & 2.02 & 0.27 & 1.21 & 0.42 \\
\hline Cobalt & $\mathrm{ppm}$ & $<0.01$ & $<0.01$ & $<0.01$ & $<0.01$ & $<0.01$ & $<0.01$ & $<0.01$ & $<0.01$ \\
\hline Nickel & $\mathrm{ppm}$ & $<0.01$ & $<0.01$ & $<0.01$ & $<0.01$ & $<0.01$ & $<0.01$ & $<0.01$ & $<0.01$ \\
\hline Copper & $\mathrm{ppm}$ & $<0.01$ & $<0.01$ & 0.09 & 0.13 & $<0.01$ & $<0.01$ & $<0.01$ & $<0.01$ \\
\hline Zinc & $\mathrm{ppm}$ & 0.04 & 0.04 & 0.04 & 0.07 & 0.03 & 0.03 & 0.04 & 0.04 \\
\hline Lead & $\mathrm{ppm}$ & $<0.01$ & $<0.01$ & 0.02 & $<0.01$ & $<0.01$ & $<0.01$ & $<0.01$ & 0.02 \\
\hline Cadmium & $\mathrm{ppm}$ & $<0.03$ & $<0.03$ & $<0.03$ & $<0.03$ & $<0.03$ & $<0.03$ & $<0.03$ & $<0.03$ \\
\hline Arsenic & $\mathrm{ppm}$ & $<0.01$ & $<0.01$ & $<0.01$ & $<0.01$ & $<0.01$ & $<0.01$ & $<0.01$ & $<0.01$ \\
\hline Mercury & $\mathrm{ppm}$ & $<0.001$ & $<0.001$ & $<0.001$ & $<0.001$ & $<0.001$ & $<0.001$ & $<0.001$ & $<0.001$ \\
\hline Chromium & $\mathrm{ppm}$ & $<0.01$ & $<0.01$ & $<0.01$ & $<0.01$ & $<0.01$ & $<0.01$ & $<0.01$ & $<0.01$ \\
\hline
\end{tabular}

Table V: Concentration of trace metals of ground water from non-industrial area (Hathazari).

\begin{tabular}{|c|c|c|c|c|c|c|c|c|c|}
\hline Metals & Units & H1 & H2 & H3 & H4 & H5 & H6 & H7 & H8 \\
\hline Magnesium & $\mathrm{ppm}$ & 20.8 & 19.2 & 38.4 & 32 & 46.4 & 31.2 & 37.6 & 300 \\
\hline Potassium & $\mathrm{ppm}$ & 3.72 & 3.19 & 2.64 & 2.93 & 4.98 & 3.22 & 2.65 & 15 \\
\hline Calcium & $\mathrm{ppm}$ & 3.2 & 4.8 & 17.6 & 24 & 50 & 18 & 12.5 & 20 \\
\hline Manganese & $\mathrm{ppm}$ & 0.01 & $<0.01$ & 0.13 & 0.08 & 0.29 & 0.25 & 0.01 & 0.34 \\
\hline Iron & $\mathrm{ppm}$ & $<0.01$ & 0.03 & 1.17 & 1.80 & 4.15 & 2.32 & 1.72 & 0.42 \\
\hline Cobalt & $\mathrm{ppm}$ & $<0.01$ & $<0.01$ & $<0.01$ & $<0.01$ & $<0.01$ & $<0.01$ & $<0.01$ & $<0.01$ \\
\hline Nickel & $\mathrm{ppm}$ & $<0.01$ & $<0.01$ & $<0.01$ & $<0.01$ & $<0.01$ & $<0.01$ & $<0.01$ & $<0.01$ \\
\hline Copper & $\mathrm{ppm}$ & $<0.01$ & $<0.01$ & $<0.01$ & 0.1 & $<0.01$ & 0.09 & $<0.01$ & $<0.01$ \\
\hline Zinc & $\mathrm{ppm}$ & 0.04 & 0.03 & 0.05 & 0.04 & 0.04 & 0.07 & 0.04 & $<0.01$ \\
\hline Lead & $\mathrm{ppm}$ & $<0.01$ & $<0.01$ & $<0.01$ & 0.01 & 0.02 & 0.01 & $<0.01$ & $<0.01$ \\
\hline Cadmium & $\mathrm{ppm}$ & $<0.003$ & $<0.003$ & $<0.003$ & $<0.003$ & $<0.003$ & $<0.003$ & $<0.003$ & $<0.003$ \\
\hline Arsenic & $\mathrm{ppm}$ & $<0.01$ & $<0.01$ & $<0.01$ & $<0.01$ & $<0.01$ & $<0.01$ & $<0.01$ & $<0.01$ \\
\hline Mercury & $\mathrm{ppm}$ & $<0.001$ & $<0.001$ & $<0.001$ & $<0.001$ & $<0.001$ & $<0.001$ & $<0.001$ & $<0.001$ \\
\hline Chromium & $\mathrm{ppm}$ & $<0.01$ & $<0.01$ & $<0.01$ & $<0.01$ & $<0.01$ & $<0.01$ & $<0.01$ & $<0.01$ \\
\hline
\end{tabular}

ppm = parts per million. 